\title{
Pleural Mesothelioma pT0 TNM Finding v7
}

National Cancer Institute

\section{Source}

National Cancer Institute. Pleural Mesothelioma pTO TNM Finding v7. NCI Thesaurus.

Code C88899.

Pleural mesothelioma without evidence of primary tumor. (from AJCC 7th Ed.) 